\title{
Role of Trace Minerals in Bolstering Reproductive Health in Heifers.
}

\author{
Nishant deep Singh Ranaut ${ }^{1}$, Anurag Borthakur ${ }^{2}$, K. Ravikanth ${ }^{2}$, Shivi Maini ${ }^{2}$ \\ ${ }^{I}$ Veterinary Polyclinic, Nahan, Distt. Sirmour, Himachal Pradesh \\ ${ }^{2} R \& D$ Deptt. Ayurvet, Baddi, Himachal Pradesh
}

\begin{abstract}
Trace minerals play a significant role in improving reproductive health. A study was carried out to evaluate the role of trace minerals in alleviating reproductive health in heifers. A total of 20 heifers were allotted into three groups TO, T1 and T2. TO (n=4) was kept as control. T1 (n=10) was supplemented with Uniselit (M/S Ayurvet) along with standard basal diet. T2 (n=6) was supplemented with CofeCu along with standard basal diet. Results revealed that there was significant improvement in the physical and chemical parameters of estrus exhibition in the Uniselit supplemented group TI as compared to control. The conception rate was also higher in group $T 1$ in comparison to control. Thus, it can be inferred that trace minerals have significant influence in improving reproductive health in heifers.
\end{abstract}

Keywords: conception rate, estrus, health, heifer, trace minerals.

\section{Introduction}

Dairy animals most commonly suffer with the nutritional deficiencies due high production and deficient feeding ultimately leading to poor reproductive performance. Micro minerals are very essential part of animal's ration which is required only in micro amount [1]. Reproductive performance in cattle, skeletal development in young animals, optimum health, and strong immunity all depend on these important trace minerals [2]. Trace minerals have critical roles in the key interrelated systems of immune function, oxidative metabolism, and energy metabolism in ruminants. To date, the primary trace elements of interest in diets for dairy cattle have included $\mathrm{Zn}, \mathrm{Cu}, \mathrm{Mn}$, and Se although data also support potentially important roles of $\mathrm{Cr}$, $\mathrm{Co}$, and Fe in diets [3]. Trace element deficiency may be linked to problems such as retained foetal membranes [4], abortion [5] and weak calf syndrome [6]. Furthermore, It has recently been reported combined selenium and iodine deficiency in a dairy herd is associated with a high incidence of retained foetal membranes, milk fever and vulval discharge [7]. Zinc is widely distributed throughout the body as a component of metalloenzymes and metalloproteins [8]. Zinc finger proteins play an integral role in regulating gene expression, consequently impacting a wide variety of body functions including cell division, growth, hormone production, metabolism, appetite control, and immune function [8][9]. Copper plays a very important role in metabolism largely because it allows many critical enzymes to function properly [10]. Vitamin E and Se are essential micronutrients that share a common biological role as antioxidants [11]. Supplementation of Se and Vitamin E have been shown to decrease the incidence of retained placenta, metritis and increased the rate of uterine involution [12]. Calcium and Phosphorus are essential to ensure proper reproductive health and productivity [13]. Phosphorus is commonly referred to as the "fertility" mineral [14]. In light of the significant role that is apportioned on the trace minerals in ameliorating reproductive health and augmenting milk production, the present study has been designed to investigate the role of trace minerals in the improvement of reproductive ability of heifers.

\section{Experimental Design}

\section{Materials and Methods}

A total of 20 Jersey or Holstein graded heifers that has exhibited estrus once, free from endometirits and having BCS (Body condition score) between 2.75- 3 were selected from Nahan town, Sirmour distt. , Himachal Pradesh. The animals were allotted into three groups T0, T1 and T2. Group T0 (n=4) was kept as control and was provided access to standard basal diet only. Group T1 $(\mathrm{n}=10)$ was supplemented with antioxidant and trace mineral supplement Uniselit (M/S Ayurvet Ltd) at the rate of 1 sachet once daily orally for 15 days along with the standard basal diet. Group T2 (n=6) was supplemented with $\mathrm{CoFeCu}$ at the rate of 2 tabs once daily orally for 15 days along with the standard basal diet. Parameters such as estrous exhibition, conception rate and body condition score were evaluated.

\section{Statistical Analysis}

The data collected was analyzed by applying standard statistical methods described by Snedecor and Cochran (1971) [15]. 


\section{Estrus Exhibition (Physical Parameters)}

\section{Results}

The physical parameters such as bellowing, mounting, restlessness, discharge, and off- feed were evaluated in the control and supplemented groups. The bellowing was found to be excellent in the Uniselit supplemented group $\mathrm{T} 1$ while it was recorded as average in the $\mathrm{CoFeCu}$ supplemented group $\mathrm{T} 2$ and control group T0 (table 1). Mounting and discharge were found to be excellent in supplemented groups T1 and T2 and average in control group T0. Off- fed behaviour manifestation was graded as average in the supplemented groups T1 and T2 relative to the control group T0 in which the off- fed behaviour was graded as poor.

Table 1: Estrus exhibition (Physical parameters) in each group of heifers.

\begin{tabular}{|l|l|l|l|l|l|}
\hline Groups & Bellowing & Off fed & Mounting & Restlessness & Discharge \\
\hline Control $(\mathrm{N}=4)$ & Average & Poor & Average & Poor & Average \\
\hline Treatment 1 $(\mathrm{N}=10)$ & Excellent & Average & Excellent & Average & Excellent \\
\hline Treatment 2 $(\mathrm{N}=6)$ & Average & Average & Excellent & Average & Excellent \\
\hline
\end{tabular}

\section{Estrus Exhibition (Chemical Parameters)}

The clinical parameters such as amount of discharge, standing estrus, tone of uterus and follicle development were also evaluated. The amount of discharge was found to be excellent in the Uniselit supplemented group T0 as compared to $\mathrm{CofeCu}$ supplemented group T2 and control group T0 (table 2). The standing estrus was recorded as average in the supplemented groups T1 and T2 and poor in the control group $\mathrm{T} 0$. The tone of uterus was found to be excellent in the supplemented groups $\mathrm{T} 1$ and $\mathrm{T} 2$ and average in the control group T0. Follicular development was maximum in the Uniselit supplemented group T1 (12.05) followed by CofeCu supplemented group T2 (11.49) as compared to the control group T0 (10.58).

Table 2: Estrus exhibition (Clinical parameters) in each group of heifers.

\begin{tabular}{|l|l|l|l|l|}
\hline Groups & $\begin{array}{l}\text { Amount of } \\
\text { discharge }\end{array}$ & $\begin{array}{l}\text { Standing } \\
\text { estrus }\end{array}$ & $\begin{array}{l}\text { Tone of } \\
\text { uterus }\end{array}$ & Follicle development \\
\hline Control $(\mathrm{N}=4)$ & Average & Poor & Average & $\mathbf{1 0 . 5 8} \pm \mathbf{0 . 6 4}^{\mathbf{A B}}$ \\
\hline Treatment 1 $(\mathrm{N}=10)$ & Excellent & Average & Excellent & $\mathbf{1 2 . 0 5} \pm \mathbf{0 . 4 1}$ \\
\hline Treatment 2 $(\mathrm{N}=6)$ & Average & Average & Excellent & $\mathbf{1 1 . 4 9 \pm 0 . 5 6}$ \\
\hline
\end{tabular}

\section{Duration of estrus exhibition}

The duration of estrus was reported to be lowest in the Uniselit supplemented group T1(28 hours) followed by $\mathrm{CoFeCu}$ supplemented group T2 (30 hours) as compared to the control group T0 (34 hours) (table $3)$.

Table 3: Duration of Estrus Exhibition in hours in each group heifers

\begin{tabular}{|l|l|}
\hline Groups & Duration Of Estrus (Av. Hr) \\
\hline Control $(\mathrm{N}=4)$ & 34 \\
\hline Treatment 1 $(\mathrm{N}=10)$ & 28 \\
\hline Treatment 2 $(\mathrm{N}=6)$ & 30 \\
\hline
\end{tabular}

\section{Conception Rate}

The conception rate was found to be highest in Uniselit supplemented group $\mathrm{T} 1(70 \%)$ followed by $\mathrm{CoFeCu}$ supplemented group T2 (66.66\%) as compared to the control group T0 (50\%) (table 4).

Table 4: Conception Rate of each group heifers

\begin{tabular}{|l|l|}
\hline Groups & Conception Rate \\
\hline Control $(\mathrm{N}=4)$ & $50 \%(2 / 4)$ \\
\hline Treatment 1 $(\mathrm{N}=10)$ & $70 \%(7 / 10)$ \\
\hline Treatment 2 $(\mathrm{N}=6)$ & $66.66 \%(4 / 6)$ \\
\hline
\end{tabular}

\section{Discussion}

The physical and chemical parameters of estrus exhibition were very prominent and the conception rate higher in the anti-oxidant and trace element supplement Uniselit administered group T1. Anti- oxidants such as vitamin E and selenium can significantly improve reproductive functions [16]. Perusal of reports also reveal that a clinical deficiency in Se can lead to many reproductive disorders such as retained placentas, infertility, cystic ovaries, metritis, delayed conception, and erratic, weak or silent heat periods leading to poor fertilization [17]. Studies have further shown that supplementation with antioxidants before the beginning of months of heat-stress and also during the stress period may correct the infertility due to heat-stress through decreased cortisol secretion and oxidative stress, resulting in enhanced pregnancy rates [18]. Thus it can be inferred that presence of anti-oxidants viz. vitamin $\mathrm{E}$ and selenium in Uniselit may have brought about the improvements in the estrus 
exhibition and conception rate. Reports also point towards a pattern of lower values of zinc and manganese being associated with increased incidence of repeat breeding cases [19]. It is suggested that Mn plays an important role within the ovary in hormone synthesis where it stimulates cholesterol synthesis which indirectly influences steroid hormone synthesis [20]. Manganese role in hormone synthesis is as a cofactor for an enzyme that converts mevalonic acid to squalene, where squalene stimulates the synthesis of cholesterol [21]. Estradiol which is secreted from the conceptus as the signal for pregnancy recognition in swine may be affected by $\mathrm{Mn}$ because of squalene's role as a precursor in steroid hormone production [22]. Zinc deficient cows appear to exhibit abnormal estrus and a decrease in fertility, but all phases of the reproductive process may be affected [23]. Thus, it can also be concluded that Zinc and manganese, which are present as trace minerals in Uniselit may have played a key role in increasing conception rate as well as better estrus exhibition. Trace mineral copper is responsible for many functions in the animal [24]. Low fertility associated with delayed or depressed oestrus have been reported in cattle graze on copper deficient pastures [25]. Cobalt is also a serious mineral limitation to livestock because even when grazing is abundant deficiency will lead to chronic starvation or wasting which is often indistinguishable from energy and protein malnutrition [26, 27, 28]. Supplementation of cobalt has been reported to improve reproductive performance in cattle [29]. Several studies suggest that deficiency in cobalt have resulted in appearance of reproductive abnormalities which include delayed uterine involution, irregular estrus cycle and decreased conception rate [30,31]. Presence of $\mathrm{Cu}$ and $\mathrm{Co}$ in Uniselit supplement further corroborate the role of trace minerals in increasing reproductive function and improving overall productivity of heifers.

\section{Conclusion}

Incorporation of trace minerals brought about significant improvements in the heifers in terms of estrus exhibition and increased conception rate. The results clearly accentuate the role of trace minerals in improving the reproductive health of heifers.

\section{Acknowledgement}

The authors are thankful to Ayurvet Limited, Baddi, India and Veterinary Polyclinic, Nahan, distt. Sirmour, Himachal Pradesh for providing the research facilities.

\section{References}

[1] S. Kumar, A.K. Pandey, W.A.A Razzaque and D.K. Dwivedi, Importance of micro minerals in reproductive performance of livestock. Veterinary World, ,4(5), 2011, 230-233.

[2] H.S. Thomas, Importance of Trace Minerals for Cattle Health and Fertility. The short round. 2011.

[3] T.R. Overton and T. Yasui, Practical applications of trace minerals for dairy cattle. J Anim Sci., 92 (2), 2014, 416-26.

[4] S. Gupta, H.K. Gupta and J Soni, Effect of vitamin E and selenium supplementation on concentrations of plasma cortisol and erythrocyte lipid peroxides and the incidence of retained foetal membranes in crossbed dairy cattle. Theriogenology, 64, 2005, $1273-1286$.

[5] J.F. Mee, The role of micronutrients in bovine periparturient problems. Cattle Practice. British Cattle Veterinary Association, Frampton-on-Severn, UK, 12, 2004, 95-108.

[6] F.F. Logan, D.A. Rice, J.A. Smyth and W.A. Ellis, Weak calf syndrome and parenteral selenium supplementation. Vet. Record, 126, 1990. 163-164.

[7] J. Husband, Retained fetal membrances and vulval discharges in a dairy herd. UK Vet., 11, 2006, 39-42.

[8] B.L.Vallee and K.H. Falchuk, The biochemical basis of zinc physiology. Physiol. Rev., 73, 1993, 79- 118.

[9] G. Predieri, M.Tegoni, E.Cinti, G. Leonardi and S. Ferruzza. Metal chelates of 2-hydroxy-4- methylthiobutanoic acid in animal feeding: preliminary investigations on stability and bioavailability., J. Inorg. Biochem 95, 2003, 221-224.

[10] E.D. Harris. Copper homeostasis: The role of cellular transporters. Nutr Rev, 59, 2001, $281-5$.

[11] J.S. Hogan, W.P. Weiss, K.L Smith, L.M. Sordillo and S.N. Williams, $\alpha$-tocopherol concentrations in milk and plasma during clinical Escherichia coli mastitis. Journal of Dairy Science, 79, 1996, 71-75.

[12] M.P. Boland, Trace Minerals in Production and Reproduction in Dairy Cows. Advances in Dairy Technology,15, 2003, 319.

[13] E.C. Phiri, R. Nkya, A.E. Pereka, M.N. Mgasa and T. Larsen, The effects of calcium, phosphorus and zinc supplementation on reproductive performance of crossbred dairy cows in Tanzania. Trop Anim Health Prod., 39(5), 2007, $317-23$.

[14] B. Yaremcio and C Kreplin, Effects of Nutrition on Beef Cow Reproduction. Agri- facts. Practical information for Alberta's Agricultural Industry. 2009.

[15] G.W. Snedecor and W.G. Cochran, Statistical Methods ( $7^{\text {th }}$ eds). IOWA: IOWA State. University Press; 1, $1971,503$.

[16] C.F. Aréchiga, O. Ortíz and P.J. Hansen, Effect of prepartum injection of vitamin E and selenium on postpartum reproductive function of dairy cattle, 41(6), 1994, 1251-8

[17] L.R. Corah and S.Ives, The Effects of Essential Trace Minerals on Reproduction in Beef Cattle. The Vet. Clinics of North America. Food Animal practice, 7, 1991, 41- 57.

[18] G.A. Megahed, M.M. Anwar and S.I. Wasfy, Influence of heat stress on the cortisol and oxidant-antioxidants balance during oestrous phase in buffalo-cows (Bubalus bubalis): thermo-protective role of antioxidant treatment. Reproduction in Domestic Animals, 43, 2008, 672-677.

[19] M. Dutta, S.N. Baruah, B.C. Sarmah and N. Baishya, Comparative study of certain micro minerals in the serum of normal and repeat breeding cross bred cows. Indian. Vet. J., 74, 2002,794-796.

[20] A. DiCostanzo, J.C. Meiske and S.D. Plegge, Influence of manganese, copper and zinc on reproductive performance of beef cows. Nutr. Rep. Int, 34, 1986, 287-293. 
[21] J.A. Olson, The biosynthesis of cholesterol. Reviews of Physiology Biochemistry and Experimental Pharmacology, 56, 1965, 173215.

[22] C.E. Hostetler, R.L. Kincaid and M.A. Mirando, The role of essential trace minerals in embryonic and fetal development in livestock. Vet. J., 166, 2003, 125-139.

[23] E.J. Underwood, The Mineral Nutrition of Livestock. Commonwealth Agricultural Bureaux 1981.

[24] A. Peters, Copper Deficiency in Beef Cattle: Pasture-Applied Copper Study in Coos County, Oregon State University, 631 Alder Street, Myrtle Point, Oregon . 2011.

[25] C. Kreplin and B. Yaremcio, Effects of nutrition on beef cow reproduction. 1992 Agdex 420/51-1.

[26] M.H. French, Mineral deficiencies in farm livestock. East African Agricultural and Forestry Journal, 10, $1952,4-8$.

[27] D.A. Howard, Notes on animal diseases. XXIII. Mineral deficiency diseases. East African Agricultural and Forestry Journal, 28, 1963, 191-194.

[28] L.R. McDowell, J.H. Conrad and G.L. Ellis, Mineral deficiencies and imbalances and their diagnosis. In: F.C.M. Gilchrist and R.I. Mackie (eds), Herbivore nutrition in the subtropics and tropics 1984, The Science Press.

[29] M.H. Campbell, J.K. Miller and F,N. Schrick, Effect of additional cobalt, copper, manganese, and zinc on reproduction and milk yield of lactating dairy cows receiving bovine somatotropin. J Dairy Sci., 82(5), 1999, 1019-25.

[30] R. Puls, Mineral Levels in Animal Health. Diagnostic Data, second Ed. Sherpa international, Clear brook, B. C Canada 1994.

[31] S. Kumar, Management of infertility due to mineral deficiency in dairy animals. In proceedings of ICAR summer school on "Advance diagnostic techniques and therapeutic approaches to metabolic and deficiency diseases 2003. 